\title{
A comparative analysis of the frictional resistance of esthetic orthodontic wires
}

\author{
Avaliação do atrito de fios ortodônticos estéticos

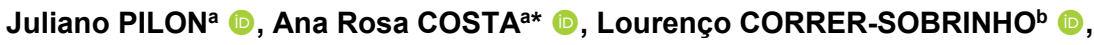 \\ Mário VEDOVELLO FILHO ${ }^{a}$ (1), Heloísa Cristina VALDRIGHIa (D) \\ aUNIARARAS/FHO - Fundação Hermínio Ometto, Programa de Pós-graduação em Ortodontia, Araras, SP, Brasil \\ bUNICAMP - Universidade Estadual de Campinas, Faculdade de Odontologia de Piracicaba, Piracicaba, SP, Brasil
}

How to cite: Pilon J, Costa AR, Correr-Sobrinho L, Vedovello Filho M, Valdrighi HC. A comparative analysis of the frictional resistance of esthetic orthodontic wires. Rev Odontol UNESP. 2019;48:e20190022. https://doi.org/10.1590/18072577.02219

\section{Resumo}

Introdução: 0 movimento ortodôntico bem sucedido está diretamente relacionado com a capacidade de os fios ortodônticos deslizarem sobre os bráquetes e tubos ortodônticos. Portanto, durante a movimentação ortodôntica a principal preocupação está diretamente ligada a fricção entre o suporte e o fio.

Objetivo: 0 objetivo deste estudo foi avaliar a influência de fios ortodônticos estéticos na resistência ao atrito. Material e método: Foram utilizados 50 bráquetes-teste divididos em 5 grupos, de acordo com o fio retangular ( $\mathrm{n}=10)$ : G1 - grupo controle: fio metálico convencional (Morelli, Brasil) e fios estéticos (G2 Ortho Organizer; G3 - Tecnident; G4 - Trianeiro; e, G5 - TP Orthodontics). Todos os fios apresentavam 0,019 x 0,025 polegadas e o bráquete era cerâmico, prescrição Edgewis e, torque e/ou angulação $0^{\circ} \mathrm{e}$, canaleta $0,022 \times 0,028$ polegadas. 0 teste de resistência ao atrito sob força de tração foi realizado em uma máquina de ensaio universal Instron à velocidade de $1,0 \mathrm{~mm} / \mathrm{min}$ e célula de carga de $500 \mathrm{~N}$. 0 s dados de resistência ao atrito foram submetidos à análise de variância (ANOVA) um fator e ao Teste de Tukey com nível de significância de 5\%. Resultado: 0 atrito $(\mathrm{N})$ do fio metálico $(8,07 \pm 0,43)$ foi significativamente maior que os fios ortodônticos estéticos: Ortho Organizer $(4,01 \pm 0,25)$, Tecnident $(3,871 \pm 0,31)$, Trident $(4,47 \pm 0,26)$ e, TP $(4,49 \pm 0,30)(\mathrm{p}<0,05)$. Nenhuma diferença estatisticamente significativa foi observada entre os fios estéticos $(p>0,05)$. Conclusão: Conclui-se que os fios ortodônticos estéticos apresentam menor resistência ao atrito quando comparado ao fio metálico.

Descritores: Fio ortodôntico; atrito; ortodontia.

\begin{abstract}
Introduction: The orthodontic movement is directly influenced by the ability of orthodontic wires to slide through brackets and tubes. Therefore, the main concern during orthodontic movement corresponds to the frictional forces generated at the bracket-orthodontic wire interface. Objective: This study aimed to evaluate the frictional resistance of esthetic orthodontic wires. Material and method: Fifty test brackets were obtained and divided into five groups $(n=10)$ based on the type of rectangular orthodontic wire, as follows: conventional metallic wire (Morelli, Brazil) (G1, control group) and esthetic wires (G2, Ortho Organizer; G3, Tecnident; G4, Trianeiro; and G5, TP Orthodontics). The following materials and conditions were used: $0.019 \times 0.025$-inch wires, ceramic brackets with edgewise prescription, torque and/or angulation of $0^{\circ}$, and $0.022 \times 0.028$-inch slots. The specimens were tested for their tensile strength using an Instron universal test machine at a speed of $1.0 \mathrm{~mm} / \mathrm{min}$ and a load cell of $500 \mathrm{~N}$. The tensile strength data were analyzed by one-way analysis of variance (ANOVA) followed by Tukey's post-hoc test, with a $5 \%$ significance level. Result: The frictional resistance $(\mathrm{N})$ of the metallic orthodontic wire $(8.07 \pm 0.43)$ was significantly higher than that of the esthetic wires: Ortho Organizer $(4.01 \pm 0.25)$, Tecnident (3.87 \pm $0.31)$, Trianeiro $(4.47 \pm 0.26)$ and TP Orthodontics $(4.49 \pm 0.30)(p<0.05)$, with no significant difference between them ( $p>0.05$ ). Conclusion: To conclude, the esthetic orthodontic wires tested herein showed less frictional resistance as compared to the conventional metallic wire.
\end{abstract}

Descriptors: Orthodontic wire; friction; orthodontics. 


\section{INTRODUCTION}

The orthodontic movement is directly influenced by the ability of orthodontic wires to slide through brackets and tubes ${ }^{1}$. This mechanics contributes to closing interdental spaces either in the initial phase of the treatment or during tooth leveling and alignment ${ }^{2}$. The main concern during orthodontic movement corresponds to the frictional forces generated at the bracketorthodontic wire interface 3,4 .

The frictional force is calculated as the coefficient of friction times the compressive force onto the surface 5 . An appropriate force intensity applied during orthodontic treatment results in tissue responsiveness and tooth movement. In contrast, excessive friction at the bracket-wire interface can prevent the application of optimal strength levels towards support tissues. Hence, knowing the intensity of the frictional force generated in the orthodontic treatment is pivotal to promote optimal biological movement of the teeth ${ }^{5,6}$. Several factors may influence the frictional force produced for tooth movement, including the type of material, bracket size and angulation, wire size and alloy, type of ligature, wire section, presence of biofilm and saliva, corrosion and load strength $5,7,8$.

Over the last years, there has been an increasing interest in orthodontic treatment with esthetic requirements by adult patients. New transparent brackets made of ceramic and polycarbonate have been engineered, as well as esthetic wires coated partially or totally with Teflon, epoxy resin, glass fiber-reinforced polymer and silicon fiber-reinforced nylon ${ }^{4,8,9}$. While esthetic brackets and wires improve the esthetics of orthodontic appliances, they present limitations such as fracture potential, abrasion of antagonist teeth and, especially, increased friction resulting from the mechanical sliding ${ }^{10}$.

Wire coating materials should fulfill the requirements of ease of application in thin layers, low frictional resistance, low coefficient of friction, biocompatibility and pleasant esthetic appearance, and compatibility with the translucency of esthetic brackets and with tooth color. While coating materials may alter some mechanical properties of the wires like attrition and friction, it is also known that Teflon-coated wires completely prevent the corrosion of esthetic orthodontic wires ${ }^{11}$.

The intensity of the frictional forces is dependent on the properties and surfaces of the orthodontic materials ${ }^{12}$. For instance, a greater friction can be observed with the increase in thickness of the wire coating material. Therefore, the coating layer of esthetic wires should ideally have a small uniform thickness ${ }^{13}$.

Thus, it is important to evaluate the contribution of esthetic coating to the frictional resistance of orthodontic wires as it interferes directly in the outcomes of the orthodontic treatment. This study analyzed comparatively the frictional resistance of different esthetic orthodontic wires. The null hypotheses tested were that (i) the frictional resistance of conventional metallic wires would be lower than that of esthetic wires, and that (ii) there would be an intergroup difference between the esthetic wires.

\section{MATERIAL AND METHOD}

\section{Specimen Preparation}

Four esthetic orthodontic wires (Ortho Organizer, USA; Tecnident, Brazil; Trianeiro, Brazil; and TP Orthodontics, USA) and one metallic wire (control group) (Morelli, Brazil) were tested. A fixed appliance segment was mounted on a rectangular acrylic plate $(4 \mathrm{~cm}$ wide $\mathrm{x} 14 \mathrm{~cm}$ long $x 0.5 \mathrm{~cm}$ thick), with a notch $(1.5 \mathrm{~cm}$ deep $\times 1.2 \mathrm{~cm}$ wide) positioned $2 \mathrm{~cm}$ from one of the ends. The appliance was composed of four metallic brackets (with edgewise prescription, 
torque and/or angulation of $0^{\circ}$ and a $0.022 \times 0.028$-inch slot) (Morelli, Brazil). The brackets were fixed with a cyanoacrylate containing instant drying glue (Super-Bonder, Loctite Henkel, Brazil) at a distance of $0.8 \mathrm{~cm}$ from each other and $1.6 \mathrm{~cm}$ from the notch region.

The distance from the upper edges of the brackets to the upper end of the plate was $0.4 \mathrm{~cm}$. Prior to bonding, the brackets were aligned using a $0.021 \mathrm{x} 0.025$-inch stainless steel wire, with the base of the bracket parallel to the acrylic plate. That wire was removed after polymerization ${ }^{14}$.

For the frictional resistance test, 5-cm segments of rectangular orthodontic wires $(0.019 \times 0.025$ inches) were used, which had their ends bent to fit the terminal brackets of the acrylic plate and not to slide through the bracket slots. For each test set, a rectangular wire $(0.019 \times 0.025$ inches) was used in combination with the test bracket (esthetic, canine, edgewise technique, $0.022 \times 0.028$-inch slot). The orthodontic wires were tied to the brackets with elastic ligatures, which were replaced after each test. The ligatures were placed with the aid of an elastic ligature applicator by embracing the mesial and distal tie wings of the brackets. In total, fifty test brackets were obtained and divided into five groups based on the type of orthodontic wire (metallic and esthetic) $(\mathrm{n}=10)$.

\section{Frictional Resistance Test}

The acrylic plate with the test set was positioned on a universal test machine (Instron Corp., Canton, MA, USA). To move the test bracket, a stainless-steel wire (Morelli, Brazil) was used, which had one of its ends attached to the system by a claw and the other end attached to the bracket, as shown in Figure 1. The test was performed under tensile strength at $1.0 \mathrm{~mm} / \mathrm{min}$ and a load cell of $500 \mathrm{~N}$.

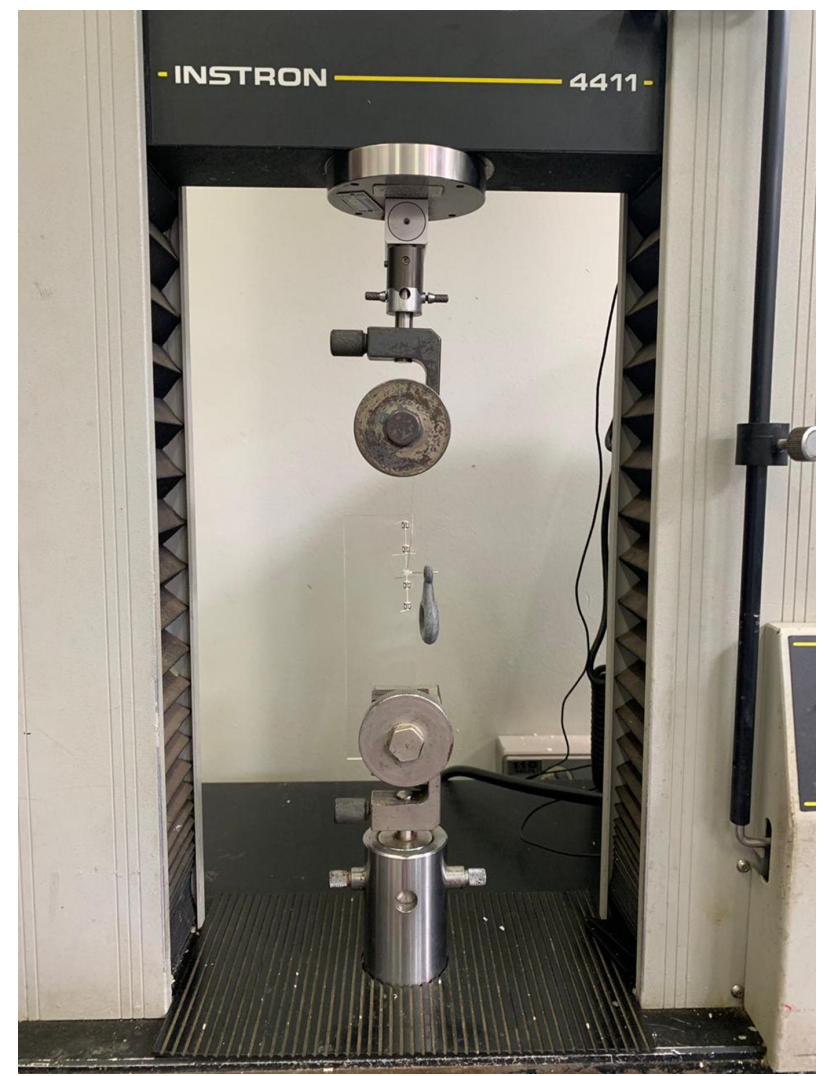

Figure 1. Frictional resistance test on a universal test machine (Instron). 


\section{Statistical Analysis}

The data were analyzed by one-way analysis of variance (ANOVA) followed by Tukey's posthoc test, with a $5 \%$ significance level.

\section{RESULT}

Results for the frictional resistance $(\mathrm{N})$ of orthodontic wire are shown in Table 1. The metallic orthodontic wire Morelli (positive control) showed a significantly higher frictional resistance than the esthetic wires $(p<0.05)$. In addition, there was no statistically significant difference between the four esthetic wire brands tested herein ( $p>0.05$ ).

Table 1. Means and standard deviation (SD) of the frictional resistance $(N)$ of orthodontic wires

\begin{tabular}{cc}
\hline Orthodontic wire & Frictional Resistance (N) \\
\hline Morelli (control group) & $8.07(0.43) \mathrm{a}$ \\
Ortho Organizer & $4.01(0.25) \mathrm{b}$ \\
Tecnident & $3.87(0.31) \mathrm{b}$ \\
Trianeiro & $4.47(0.26) \mathrm{b}$ \\
TP Orthodontics & $4.49(0.30) \mathrm{b}$ \\
\hline
\end{tabular}

Different letters indicate statistically significant differences $(\mathrm{p}<0.05)$.

\section{DISCUSSION}

Several types of materials have been used in the manufacture of orthodontic brackets and arch wires. Brackets and wires coated with non-metallic materials (e.g. polyethylene, polytetrafluoroethylene and epoxy resin) are used when there is an esthetic requirement during the orthodontic treatment and to reduce the frictional force that occurs upon mechanical sliding of the wire through the bracket ${ }^{7}$. Hence, it is necessary to know the materials used in the orthodontic treatment, particularly because the intensity of the frictional force is closely related to the properties and surfaces of the materials ${ }^{12}$.

The first hypothesis tested in our study was rejected. According to the findings, the metallic orthodontic wire presented a greater frictional resistance than the esthetic wires. Previous studies,15-18 have shown that esthetic brackets have reduced roughness and lower friction when compared to conventional stainless-steel brackets. In the scientific literature, the studies analyzing the frictional resistance of different brackets have reported inconsistent findings due to the different methodologies used, in particular: orthodontic wires and brackets of different manufacturers, different combinations of bracket and wire, distinct test conditions (dry or saliva/other solutions-moistened environment), and different bracket angulations. All these factors make it difficult to compare the results between the studies. In general, the smoother surface of the ceramic brackets is believed to contribute to less resistance to friction and mechanical sliding 17,18 .

The wire/bracket combination used in our study might have influenced the results. Only ceramic brackets were used, which might have produced less friction of the esthetic wires during mechanical sliding through the bracket. In addition, Downing et al.19 and Kusy, Whitley ${ }^{20}$ observed that the wire material has little influence on the frictional force. In contrast, Braga et al. ${ }^{21}$ found that esthetic wires produce higher friction when compared to stainless-steel wires and pointed out that the differences observed might be related to the surface texture of the brackets. Moreover, the higher frictional resistance found for metallic wires can be explained by the difference in the friction levels between the different tested wires. Of note, 
there are important differences in the structure of the materials and composition of the dowel, which results in different surface textures ${ }^{22}$.

Since no statistical difference was observed among the different esthetic wires, the second hypothesis tested in our study was also rejected. The esthetic wires tested herein are Teflon coated, which may explain the lack of difference between them. One of the parameters directly influencing the friction of orthodontic wires is surface roughness ${ }^{23}$. Resin-coated wires have reduced surface roughness as compared to metallic ones, which facilitates mechanical sliding. In most cases, esthetic wires have a smoother surface and therefore present a lower frictional force ${ }^{24}$. It can be speculated that the esthetic orthodontic wires tested in our study showed a similar surface smoothness and reduced roughness as compared to the conventional metallic wire.

Although the frictional resistance of the esthetic wires was found to be lower than that of the metallic wire, one should consider that the esthetic coating has a low resistance within the oral milieu and, with continuous use, it may fracture and impair the overall esthetics of the system. This results in increased surface roughness and friction during therapy. All the esthetic wires tested herein have a Teflon coating, which presents a good corrosive property when in contact with the oral environment 20 .

Taken altogether, the results suggest that frictional forces increase depending on the orthodontic wire and that conventional stainless-steel metallic wires have greater frictional resistance. However, clinicians should be cautious when interpreting the results of laboratory friction studies, since in vitro experimentation of shear resistance using static traction applied onto the bracket/wire interface does not accurately represent the complexity of tooth movement. Even so, it remains a widely used approach, which can be applied to test hypothesis regarding the reduction of frictional forces ${ }^{25}$.

Thus, several other properties in addition to esthetics must be considered when choosing the ideal orthodontic wire, which include biocompatibility and resilience.

\section{CONCLUSION}

To conclude, (i) the esthetic orthodontic wires tested herein showed less frictional resistance as compared to the conventional metallic wire and (ii) similar frictional resistance when compared to each other.

\section{REFERENCES}

1. Bortoly TG, Guerrero AP, Rached RN, Tanaka O, Guariza-Filho O, Rosa EA. Sliding resistance with esthetic ligatures: an in-vitro study. Am J Orthod Dentofacial Orthop. 2008 Mar;133(3):340.e1-7. http://dx.doi.org/10.1016/j.ajodo.2007.08.015. PMid:18331929.

2. Burrow SJ. Friction and resistance to sliding in orthodontics: a critical review. Am J Orthod Dentofacial Orthop. 2009 Apr;135(4):442-7. http://dx.doi.org/10.1016/j.ajodo.2008.09.023. PMid:19361729.

3. Muguruma T, Iijima M, Brantley WA, Ahluwalia KS, Kohda N, Mizoguchi I. Effects of third-order torque on frictional force of self-ligating brackets. Angle Orthod. 2014 Nov;84(6):1054-61. http://dx.doi.org/10.2319/111913-845.1. PMid:24738791.

4. Shirakawa N, Iwata T, Miyake S, Otuka T, Koizumi S, Kawata T. Mechanical properties of orthodontic wires covered with a polyether ether ketone tube. Angle Orthod. 2018 Jul;88(4):442-9. http://dx.doi.org/10.2319/082417-572.1. PMid:29561658. 
5. Arici N, Akdeniz BS, Arici S. Comparison of the frictional characteristics of aesthetic orthodontic brackets measured using a modified in vitro technique. Korean J Orthod. 2015 Jan;45(1):29-37. http://dx.doi.org/10.4041/kjod.2015.45.1.29. PMid:25667915.

6. Ogata RH, Nanda RS, Duncanson MG Jr, Sinha PK, Currier GF. Frictional resistances in stainless steel bracket-wire combinations with effects of vertical deflections. Am J Orthod Dentofacial Orthop. 1996 May;109(5):535-42. http://dx.doi.org/10.1016/S0889-5406(96)70139-7. PMid:8638599.

7. Husmann $P$, Bourauel C, Wessinger $M$, Jäger A. The frictional behavior of coated guiding archwires. J Orofac Orthop. 2002 May;63(3):199-211. http://dx.doi.org/10.1007/s00056-002-0009-5. PMid:12132308.

8. Eliades T. Orthodontic materials research and applications: part 2. Current status and projected future developments in materials and biocompatibility. Am J Orthod Dentofacial Orthop. 2007 Feb;131(2):253-62. http://dx.doi.org/10.1016/j.ajodo.2005.12.029. PMid:17276868.

9. Kim Y, Cha JY, Hwang CJ, Yu HS, Tahk SG. Comparison of frictional forces between aesthetic orthodontic coated wires and self-ligation brackets. Korean J Orthod. 2014 Jul;44(4):157-67. http://dx.doi.org/10.4041/kjod.2014.44.4.157. PMid:25133130.

10. Reicheneder CA, Baumert U, Gedrange T, Proff P, Faltermeier A, Muessig D. Frictional properties of aesthetic brackets. Eur J Orthod. 2007 Aug;29(4):359-65. http://dx.doi.org/10.1093/ejo/cjm033. PMid:17702795.

11. Kusy RP. A review of contemporary archwires: their properties and characteristics. Angle Orthod. 1997;67(3):197-207. http://dx.doi.org/10.1043/0003-3219(1997)067<0197:AROCAT>2.3.CO;2. PMid:9188964.

12. Park JH, Lee YK, Lim BS, Kim CW. Frictional forces between lingual brackets and archwires measured by a friction tester. Angle Orthod. 2004 Dec;74(6):816-24. http://dx.doi.org/10.1043/00033219(2004)074<0816:FFBLBA>2.0.C0;2. PMid:15673146.

13. Bandeira AM, dos Santos MP, Pulitini G, Elias CN, da Costa MF. Influence of thermal or chemical degradation on the frictional force of an experimental coated NiTi wire. Angle Orthod. 2011 May;81(3):484-9. http://dx.doi.org/10.2319/042810-232.1. PMid:21299382.

14. Venâncio FR, Vedovello SAS, Tubel CAM, Degan VV, Lucato AS, Lealdim LN. Effect of elastomeric ligatures on frictional forces between the archwire and orthodontic bracket. Braz J Oral Sci. 2013 Mar;12(1):41-5. http://dx.doi.org/10.1590/S1677-32252013000100009.

15. Ireland AJ, Sherriff M, McDonald F. Effect of bracket and wire composition on frictional forces. Eur J Orthod. 1991 Aug;13(4):322-8. http://dx.doi.org/10.1093/ejo/13.4.322. PMid:1915622.

16. Matasa CG. Encaixe do bráquete examinado através do microscópio de força atômica (MFA). Rev Dental Press Ortodon Ortop Maxilar. 1997;2:60-75.

17. Singh V, Acharya S, Patnaik S, Nanda SB. Comparative evaluation of frictional forces between different archwire-bracket combinations. Orthod J Nepal. 2014;1(1):22-8. http://dx.doi.org/10.3126/ojn.v4i1.11307.

18. Arash V, Rabiee M, Rakhshan V, Khorasani S, Sobouti F. In vitro evaluation of frictional forces of two ceramic orthodontic brackets versus a stainless steel bracket in combination with two types of archwires. J Orthod Sci. 2015 Apr-Jun;4(2):42-6. http://dx.doi.org/10.4103/2278-0203.156028. PMid:26020037.

19. Downing A, McCabe J, Gordon P. A study of frictional forces between orthodontic brackets and archwires. Br J Orthod. 1994 Nov;21(4):349-57. http://dx.doi.org/10.1179/bjo.21.4.349. PMid:7857894.

20. Kusy RP, Whitley JQ. Frictional resistences of metal-lined ceramic brackets versus conventional stainless steel brackets and development of 3-D friction maps. Angle Orthod. 2001 Oct;71(5):364-74. http://dx.doi.org/10.1043/0003-3219(2001)071<0364:FROMLC>2.0.CO;2. PMid:11605870. 
21. Braga CP, Vanzin GD, Marchioro EM, Beck JCP. Avaliação do coeficiente de atrito de bráquetes metálicos e estéticos com fios de aço inoxidável e beta-titânio. Rev Dent Press Ortodon Ortop Facial. 2004 Dez;9(6):70-83. http://dx.doi.org/10.1590/S1415-54192004000600011.

22. Shivapuja PK, Berger J. A comparative study of conventional ligation and self-ligation bracket systems. Am J Orthod Dentofacial Orthop. 1994 Nov;106(5):472-80. http://dx.doi.org/10.1016/S08895406(94)70069-9. PMid:7977187.

23. Jakob SR, Matheus D, Jimenez-Pellegrin MC, Turssi CP, Amaral FL. Comparative study of friction between metallic and conventional interactive self-ligating brackets in different alignment conditions. Dental Press J Orthod. 2014 May-Jun;19(3):82-9. http://dx.doi.org/10.1590/2176-9451.19.3.082089.oar. PMid:25162570.

24. Karamouzos A, Athanasiou AE, Papadopoulos MA. Clinical characteristics and properties of ceramic brackets: a comprehensive review. Am J Orthod Dentofacial Orthop. 1997 Jul;112(1):34-40. http://dx.doi.org/10.1016/S0889-5406(97)70271-3. PMid:9228839.

25. Pacheco MR, Oliveira DD, Smith Neto P, Jansen WC. Avaliação do atrito em bráquetes autoligáveis submetidos à mecânica de deslizamento: um estudo in vitro. Dental Press J Orthod. 2011 Fev;16(1):107-15. http://dx.doi.org/10.1590/S2176-94512011000100016.

\section{CONFLICTS OF INTERESTS}

The authors declare no conflicts of interest.

\section{${ }^{*}$ CORRESPONDING AUTHOR}

Ana Rosa Costa, UNIARARAS/FHO - Fundação Hermínio Ometto, Programa de Pósgraduação em Ortodontia, Av. Dr. Maximiliano Baruto, 500, Jardim Universitário, 13607-339 Araras - SP, Brasil, e-mail: anarosacosta_1@hotmail.com

Received: March 11, 2019

Accepted: June 12, 2019 